\title{
Coproduction of Food, Cultural Heritage and Biodiversity by Livestock Grazing in Swedish Semi-natural Grasslands
}

\author{
Ove Eriksson * \\ Department of Ecology, Environment and Plant Sciences, Stockholm University, Stockholm, Sweden
}

\section{OPEN ACCESS}

Edited by:

Samir Sayadi Gmada, Andalusian Institute for Research and Training in Agriculture, Spain

Reviewed by:

Russell Hedberg, Shippensburg University,

United States

Robert J. Hijmans, University of California, Davis, United States

*Correspondence: Ove Eriksson ove.eriksson@su.se

Specialty section:

This article was submitted to Agroecology and Ecosystem Services,

a section of the journal

Frontiers in Sustainable Food Systems

Received: 25 October 2021

Accepted: 21 January 2022

Published: 15 February 2022

Citation:

Eriksson O (2022) Coproduction of

Food, Cultural Heritage and Biodiversity by Livestock Grazing in Swedish Semi-natural Grasslands. Front. Sustain. Food Syst. 6:801327. doi: 10.3389/fsufs.2022.801327
Livestock has been a backbone of people's livelihood as long as agriculture has existed in Scandinavia, c. 6,000 years. In the early Iron Age, c. 2,000 years ago, a land management system began to form, composed of infields (enclosed hay-meadows and crop fields) and outlying land used for livestock grazing. Despite many later innovations and societal changes affecting agricultural technology and practices, this way of organizing land use was a template for how landscapes were managed and structured until the modernization of agriculture and forestry during the last centuries. There are legacies of this historic land-use, mainly as "semi-natural grasslands" managed by livestock grazing (open or semi-open; long continuity of management; not much influenced by commercial fertilizers, plowing etc.). These semi-natural grasslands harbor an exceptional small-scale biodiversity, particularly plants and insects. Landscapes with semi-natural grasslands represent cultural heritage, and are appreciated for their beauty. The total area of semi-natural grasslands has declined considerably during the past 100 years, and the current trend suggest that further declines are expected. A large fraction of threatened biodiversity in Sweden thrives in these grasslands. Livestock grazing in semi-natural grasslands makes an important contribution to food production, and there is an increasing interest in consumption of products, mainly meat, from these grasslands. This implies that there is a positive feedback between food production, maintenance of biological diversity, and cultural heritage. This paper gives an overview of semi-natural grasslands, focusing on Sweden, from a historic, cultural and ecological perspective, and aims at discussing challenges and prospects for developing and maintaining positive associations between producing food, biodiversity, and cultural heritage, in the future.

Keywords: conservation biology, land-use history, rural landscapes, shielings, species richness, sustainable food

\section{INTRODUCTION}

Agricultural systems based on livestock are ubiquitous globally. It has been estimated that around $40 \%$ of global agricultural gross domestic product derives from livestock, and around a third of the world's terrestrial ice-free surface is to some extent used for livestock (Herrero et al., 2013). The total biomass of livestock on Earth by far exceeds the biomass of all other mammals taken together (Bar-On et al., 2018). Various aspects regarding livestock are key issues in the current discourse on sustainable food production in a world of changing climate, declining biodiversity, and urgent 
needs of food security (e.g., Phalan et al., 2011; Herrero et al., 2013; Gerber et al., 2015; Mottet et al., 2017; Mehrabi et al., 2018; Springmann et al., 2018; Willett et al., 2019). As pointed out by some of these authors, it is important not to generalize as if livestock production is universally similar. There are great differences geographically and culturally. Although industrialized meat production is in focus of current concerns, both from environmental and animal welfare perspectives, only between 7 and 13\% of beef production, globally, comes from fully industrialized, so called feedlot systems (Gerber et al., 2015; Mottet et al., 2017).

Furthermore, keeping livestock goes back to the dawn of agriculture (e.g., Zeder, 2011). For regions where agriculture arrived later, livestock was an integral part from the beginning. For example, when the first agriculturalists arrived to northern Europe and ultimately reached southern Scandinavia (presentday Sweden) around 4000 BCE, they brought with them livestock, mainly cattle and sheep (e.g., Rowley-Conwy, 2011; McClure, 2015). Although the management of land and livestock of course has changed fundamentally since that time, there are indeed many traces in today's agricultural landscapes that has a deep history, motivating terms such as historical, or traditional, agricultural management. This holds for Scandinavia (e.g., Eriksson, 2018), as well as for all over Europe (e.g., Blondel, 2006; Emanuelsson, 2009; Lennartsson et al., 2016; Dobrovodská et al., 2019), and other parts of the world, for example Asia (e.g., Yi et al., 2008; Berglund et al., 2014), and Africa (e.g., Boles and Lane, 2016; Van der Plas et al., 2019). Thus, many features of agriculture are part of cultural heritage, manifested also biologically (e.g., Antrop, 2005; Rotherham, 2015; Eriksson, 2018).

From a biological viewpoint, remains of traditional agricultural landscapes (used here for landscapes which retain traces of management systems rooted in pre-industrial times) are often highlighted for their species richness. In fact, temperate and boreal grasslands with a long history of management (grazing, mowing), usually labeled "semi-natural grasslands," contain the highest small-scale (plot-scale, one or a few $\mathrm{m}^{2}$ ) plant species richness on Earth (Wilson et al., 2012). Also other taxa, for example insects and fungi, are particularly species-rich in semi-natural grasslands (e.g., Eriksson, 2021). Taking Sweden as an example, around a third of all red-listed species have their main occurrence in agricultural landscapes with remaining semi-natural grasslands (Eide et al., 2020). A part of the explanation for the large number of threatened species is that semi-natural habitats have declined drastically during the last 100-150 years (e.g., Eriksson and Cousins, 2014; Cousins et al., 2015; Aune et al., 2018). Currently there are slightly more than 400,000 hectares of semi-natural grasslands in Sweden, approximately half of which are considered especially valuable from a biodiversity viewpoint (Swedish Board of Agriculture, 2019a).

Despite the importance of traditional landscapes for biodiversity is now well-known (e.g., Bignal and McCracken, 1996; Emanuelsson, 2009; Veen et al., 2009; Plieninger et al., 2015; Herzon et al., 2021), and farmers in Sweden may receive subsidies for maintaining management of semi-natural grasslands, there is still an ongoing negative trend both in terms of the area of semi-natural grasslands in Sweden and regarding the status for threatened species in these landscapes (Swedish Board of Agriculture, 2019a; Swedish Environmental Protection Agency, 2019).

The objectives of this paper are 2-fold. Firstly, I will briefly review the history of semi-natural grasslands in Sweden, with a focus on biodiversity and cultural heritage. Secondly, I will discuss the prospects for a continuing and strengthened synergism between food production and maintenance of biodiversity and cultural heritage in semi-natural grasslands. An overarching question is whether there is a future for landscapes harboring the still existing biologically highly diverse, culturally highly valued, and (for many people) beautiful seminatural grasslands.

\section{A BRIEF HISTORY OF SEMI-NATURAL GRASSLANDS IN SWEDEN}

Semi-natural grasslands in Sweden (Figures 1, 2) are formed by human intervention. Most of Sweden is part of the boreal vegetation zone, i.e., the natural forest cover is dominated by coniferous tree species, mainly Scots pine (Pinus sylvestris) and Norway spruce (Picea abies), and a few deciduous species, such as birch (Betula spp.). The southern part of the boreal zone is usually considered as a transition to the nemoral zone. This transition zone, the boreo-nemoral zone (Sjörs, 1999), where most of today's still remaining semi-natural grasslands in Sweden occur, has a natural forest cover which also includes several deciduous tree species, for example oak (Quercus robur), ash (Fraxinus excelsior) and elm (Ulmus glabra), and large shrubs such as hazel (Corylus avellana). The term "semi-natural" stems from the fact that the species-pool of these grasslands is mainly composed of native species, and the grasslands are only to a limited extent influenced by management such as plowing, fertilization or sowing. In order to create a semi-natural grassland, the original forest cover was cleared, either manually or by burning. Such clearing of forests started already when the first agriculturalist arrived c. 6,000 years ago. During the millennia after the arrival of agriculture, i.e., from the Neolithic onwards, through the Bronze Age (in Sweden: 1800-500 BCE), and the Iron Age (in Sweden: 500 BCE-1050 $\mathrm{CE})$, the landscape in southern Scandinavia became successively more open (Berglund et al., 2008). This trend continued until the early 20th century, after which the forest cover has expanded (O'Dwyer et al., 2021).

Although it is reasonable that the open or semi-open landscapes from the late Neolithic and throughout the Bronze Age (e.g., Kristiansen, 2007) contained what we today would recognize as semi-natural grasslands, it is difficult to detect a direct link from so far back in time to the grasslands we have today. However, such links start to become detectable approximately from 2,000 years ago, i.e., the early Iron Age. The background is that land use and the organization of land was transformed during a period from the first millennium $\mathrm{BCE}$ to the first centuries CE. The reasons behind this transformation were complex, and involved several components: 


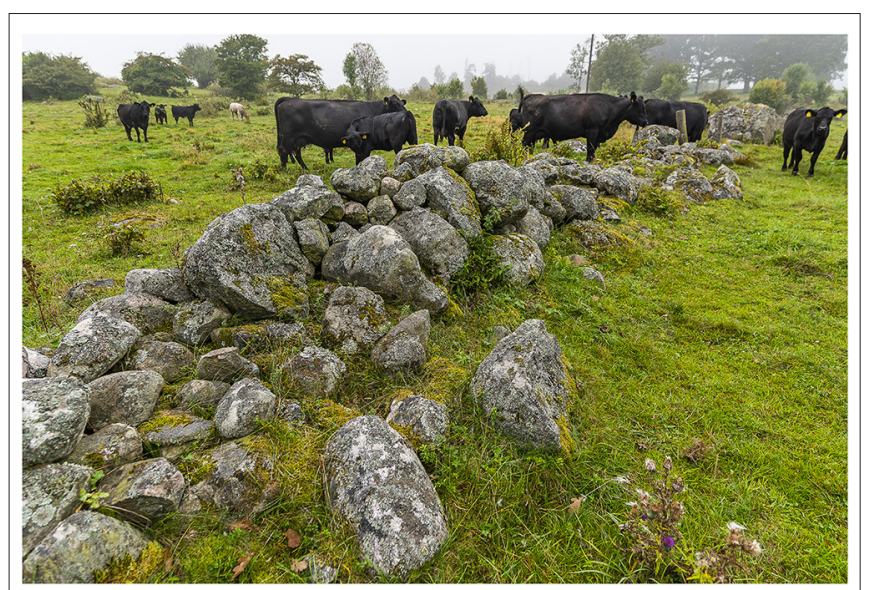

FIGURE 1 | Young Aberdeen Angus cattle in a semi-natural grassland in the Province of Närke, Sweden. The stone wall formerly enclosed the infields (Photo: Ola Jennersten).

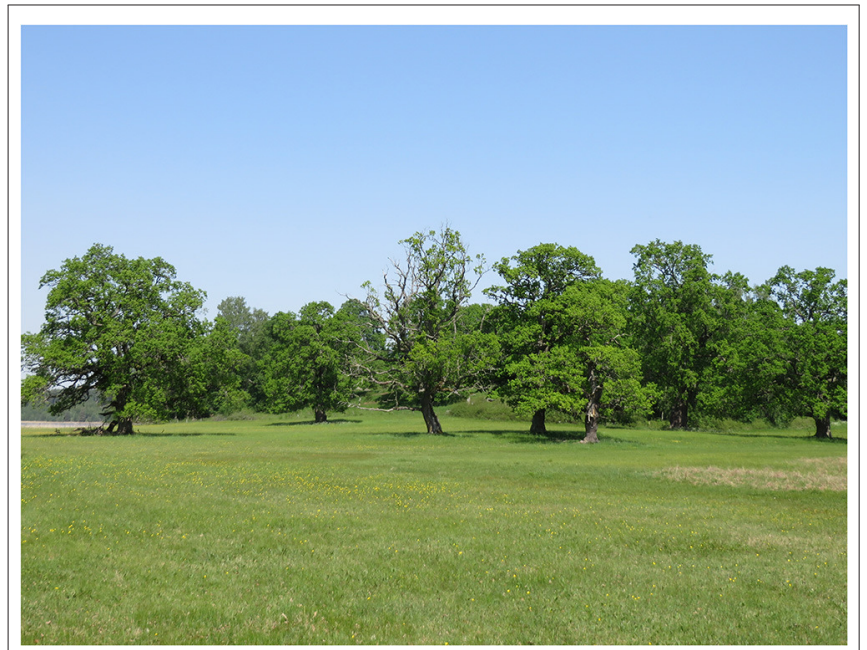

FIGURE 2 | A semi-natural grassland with scattered stands of oak (Quercus robur) from the Province of Södermanland, Sweden (Photo: The author).

a spread of cultural influences from continental Europe regarding management of crop fields, the choice of crops, handling of livestock, including an increase in keeping livestock indoors during winters, organization of land, and the probable introduction of what we today would regard as "private" land ownership (see Eriksson, 2020 for a review of this transition).

On these northern latitudes, keeping livestock was a key to survival for people, as the conditions are not perfectly suitable for crop production. Thus, vast areas were used for production of hay (grasses, herbs and leaf-hay) used as winter fodder for the livestock. A key factor in the transition was therefore the availability of iron for agricultural tools and implements necessary for the management of hay-meadows on infields, i.e., enclosed areas surrounding farms, and excluding, or controlling, livestock grazing. The high work-load invested in meadow management probably contributed to make settlements more stable, i.e., located at the same place for long periods of time. Livestock grazing mainly took place outside the enclosures, in the outlying land. Although climate change is not likely to have been an initial driver behind the expansion of hay-meadows (Widgren, 2012; Eriksson, 2020), an agricultural system based on livestock was adaptive, especially during periods of climate cooling, such as the Little Ice Age between the 14th and 19th centuries CE (Wanner et al., 2008).

During the recent centuries, from the early 18th and through the 19th century, Swedish agriculture underwent drastic changes, sometimes termed an "agricultural revolution" (Gadd, 2011). Again, the underlying reasons for these changes were complex, but it was generally driven by an objective to increase agricultural production with the aid of new agricultural techniques, and by exploiting new land for agriculture, for example in forested regions, and by draining of wetlands (Gadd, 2011; Eriksson et al., 2021). The total area of crop fields increased. Livestock fodder were increasingly produced on fields, and hence the traditional hay-meadows became obsolete. Commercial fertilizers were introduced. The growing forestry industry created a conflict between livestock grazing in forests and production of timber and pulp. Thus, forest grazing decreased and was ultimately more or less abandoned during the early 20th century (e.g., Kardell, 2016). Forests thereby became decoupled from agriculture, and, as a result of an increasing use of commercial fertilizers (and less use of manure), livestock and crop production became partly decoupled (Eriksson et al., 2021).

The total area of semi-natural grasslands declined drastically already during the 19th century (e.g., Dahlström et al., 2006), and this decline continued during the $20^{\text {th }}$ century. Estimates suggest an overall decline with more than $90 \%$ in some regions since the early 20th century (Eriksson and Cousins, 2014; Cousins et al., 2015). The area used for forest grazing has declined with over 98\% since 1927 (Swedish Board of Agriculture, 2019b).

Some semi-natural grasslands did however maintain a function in the continuously modernized landscape, and were used for livestock grazing in the vicinity of farms. Livestock was now fenced-in, instead of, as previously, largely grazing in forests (which were semi-open) outside the infield enclosures. Thus, remaining semi-natural grasslands often have a previous history as infield hay-meadows (Cousins, 2001; Eriksson and Cousins, 2014). In terms of management continuity, many semi-natural grasslands have existed for many centuries, and some of them may even be traced back to the Iron Age. Thus, these grasslands in some cases represent biological cultural heritage older than for example the oldest known buildings in Scandinavia.

\section{BIODIVERSITY IN SEMI-NATURAL GRASSLANDS}

Two of Sweden's Environmental Objectives, "A rich diversity of plant and animal life" (Swedish Environmental Protection Agency, 2019) and "A varied agricultural landscape" (Swedish Board of Agriculture, 2019a) specifically highlight the importance of semi-natural grasslands for biodiversity. 


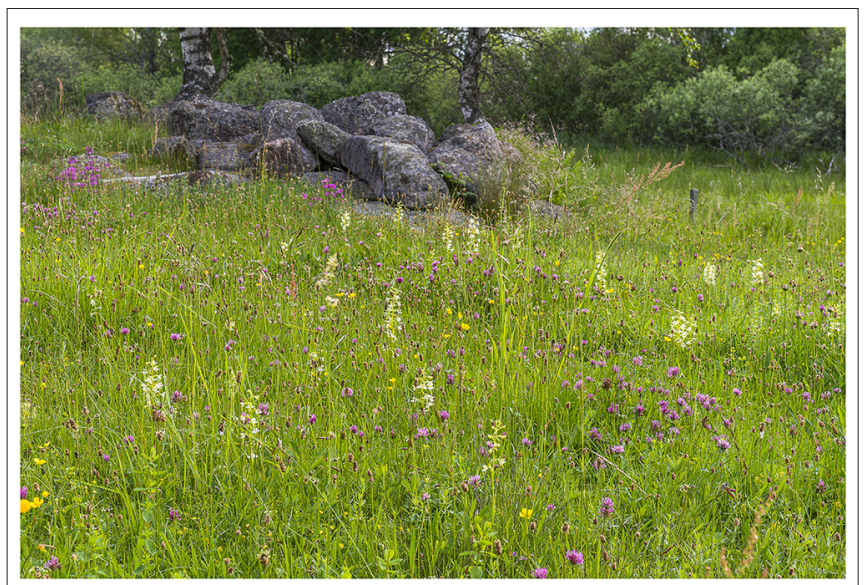

FIGURE 3 | Semi-natural grasslands harbor a rich diversity of flowering plants, typically most conspicuous if grazing starts late during the summer season (Photo: Ola Jennersten).

Plants constitute the basis for biodiversity in semi-natural grasslands. There is an exceptionally high small-scale richness of plant species in these grasslands (Figure 3); around 40 plant species per $\mathrm{m}^{2}$, occasionally even more, is not uncommon (e.g., Eriksson et al., 2006; Cousins, 2009). There are two categories of underlying ecological mechanisms behind this plant species richness, one acting on the local scale and one acting on the landscape scale. Firstly, the continuing removal of biomass due to hay-harvest (historically) and livestock grazing means that strongly competitive species are hindered to become dominant (Grime, 1979; Diekmann et al., 2004). Dominance of competitive species is further counteracted by low nutrient levels, as these grasslands are not subjected to commercial fertilizers. Litter does not accumulate (Quested et al., 2007), and together with various types of small-scale disturbance this creates suitable conditions for plant recruitment (Eriksson and Eriksson, 1997; Rook et al., 2004). Small-scale species richness may actually promote seedling recruitment (Franzén, 2001; Eriksson et al., 2006). Altogether, these mechanisms allow co-existence of many species, even small-statured species with limited competitive ability (Grubb, 1977; Ekstam and Forshed, 1992). Secondly, due to the persistence in space and time of the grasslands, there is ample time for species in the regional species pool to colonize each grassland site (Eriksson, 2013; Marteinsdóttir and Eriksson, 2014). Historical management (movement of people and livestock, transport of hay) also promoted seed dispersal among grassland sites (e.g., Bruun and Fritzbøger, 2002).

Also other taxa have a high species richness in semi-natural grasslands, for example insects (e.g., Dover et al., 2011; Milberg et al., 2016; Mäkeläinen et al., 2019), birds (e.g., Manton and Angelstam, 2018) and fungi (Rydin et al., 1997). Continuing management is essential for maintaining this high biodiversity (Figure 4). Abandonment of management in landscapes with semi-natural grasslands is expected to result in elevated regional species extinction rates (Eriksson, 2021). However, it is possible that the addition and maintenance of new landscape elements such as road verges and power line corridors at least to some

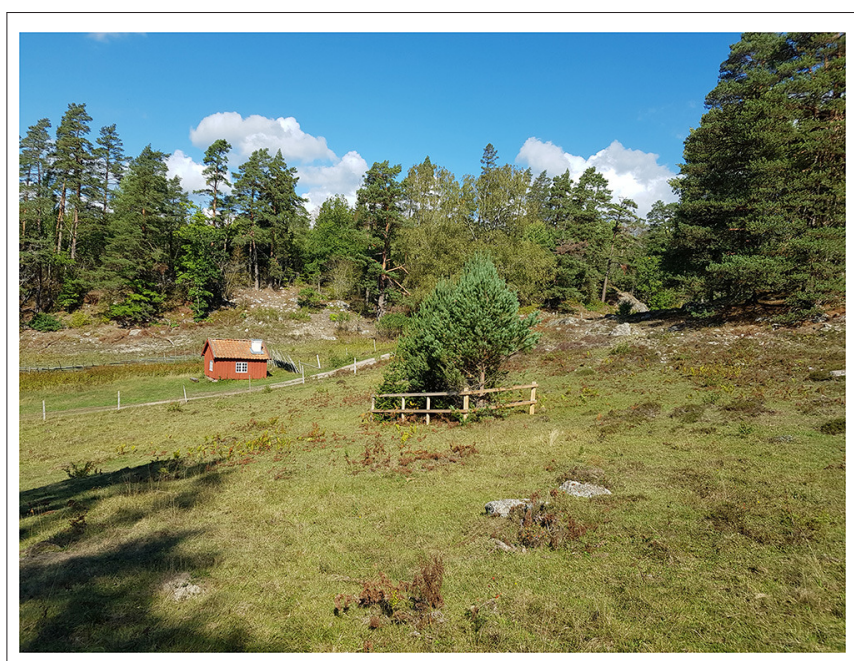

FIGURE 4 | A livestock exclosure raised in 2004 in a semi-natural grassland in the Province of Södermanland, Sweden, illustrates what would happen if livestock grazing is abandoned. The photo was taken 2018 (Photo: The author).

extent may alleviate these effects (Auestad et al., 2011; Berg et al., 2011).

There is plenty of evidence suggesting that historic continuity of management, mowing or grazing, is positively associated with plant species richness (Cousins and Eriksson, 2002; Pykälä, 2004; Gustavsson et al., 2007; Johansson et al., 2008; Cousins, 2009). Studies on the effects of land-use history on current species richness have mostly concerned plant communities, but similar historical effects have been found also for other taxa. For example, diversity of insect pollinators is positively associated with a long management history (Cusser et al., 2018), and continuously low to intermediate levels of land-use intensity, which is a feature of semi-natural grasslands, is generally positive for pollinator diversity (Millard et al., 2021).

Despite the large landscape changes during the last 100-150 years, patterns of plant species diversity remain as a signal of past grassland management even in strongly transformed landscapes (Lindborg and Eriksson, 2004; Helm et al., 2006; Johansson et al., 2011), and also in production forests (Milberg et al., 2019). Thus, there is a potential for restoration of semi-natural grasslands, and at least restore parts of the former species richness (Waldén and Lindborg, 2016).

As most remaining semi-natural grasslands are located on former infields (see the preceding section), it is likely that they have a history as hay-meadows. As described above such infield hay-meadows were later (during late 19th to early 20th century) used permanently for livestock grazing. It is thus reasonable that the current species richness reflects the historic land-use (production of hay), something which in turn would imply that continuous grazing throughout the vegetation season may not be optimal for many species. Indeed, starting grazing late in season is beneficial for many insects (Lenoir and Lennartsson, 2010), and for some plant species (Glav Lundin and Eriksson, 2021). As variation in hay-harvest timing (between 
sites and years) also occurred historically (Eriksson et al., 2015), this would add another element of heterogeneity to grassland management, beneficial for biodiversity (Johansen et al., 2019). Thus, biodiversity in agricultural landscapes reflects occurring features of traditional management, including heterogeneity with regard to a variety of habitats, and semi-natural grasslands subjected to intermediately intensive grazing, for example conducted mostly during the latter part of the vegetation season.

Before agriculture, northern Europe was dominated by forests (Roberts et al., 2018). Although some naturally open preagricultural habitats existed (e.g., Svenning, 2002; Auffret and Cousins, 2018), one may ask where (ecologically) the rich species pool now inhabiting traditional agricultural landscapes existed before agriculture. It is likely that agriculture implied human niche construction favoring this species pool (Eriksson, 2013), but where did it come from? Only few evolutionary adaptations have been documented, and few, if any, new species have originated during the six millennia since agriculture arrived (MacDougall et al., 2018). The most likely answer is that the rich diversity of species in traditional agricultural landscapes reflects a species pool which once inhabited Pleistocene landscapes, strongly impacted by now extinct species of grazing megaherbivores (Johnson, 2009; Gill, 2013; Eriksson, 2021). If this interpretation is correct, agriculture may in fact have rescued a species pool which otherwise would have faced risk of extinction due to the demise of the megaherbivores.

\section{CULTURAL HERITAGE IN SEMI-NATURAL GRASSLANDS}

Heritage is a contested concept (e.g., Smith, 2006), and the same holds for the term traditional. For example, as remarked by Stenseke (2016, p. 202): “Although the features and structures the management is aimed at maintaining are most often a result of past land use, it is the forms, the functions, the processes and the context at present that constitute the basis for actions." Hence, a common theme in heritage studies is the idea that heritage and traditions, and values associated with them, are continuously produced (constructed, re-negotiated) (e.g., Hobsbawn, 1983; Smith, 2006; Braaksma et al., 2016; Bele et al., 2018). What is valued as cultural heritage is not fixed. Landscapes have sometimes metaphorically been considered as a palimpsest, composed of layers of features representing remains of human activities from different times (e.g., Svensson et al., 2018). These layers can be manifested biologically (e.g. vegetation patterns), materially (e.g., buildings) as well as immaterially (e.g., memories).

Whether these layered features are recognized and valued as heritage is in itself context-dependent. For example, Eriksson (2018) compared Swedish forests with rural landscapes with regard to perceptions of heritage. While the extensive historical use of forests as part of agriculture (mainly livestock grazing) and for production of charcoal, tar etc. largely has been forgotten by people, and is overlooked by forest companies, land managers and conservation authorities--a kind of collective memory loss--agricultural landscapes with semi-natural grasslands are still generally valued as part of cultural heritage.
For cultural landscapes with "outstanding universal value," UNESCO World Heritage Convention recognizes, as one specific category, "organically evolved landscapes, such as agricultural landscapes" (Rössler, 2006). The values highlighted are, for example, historical identity, living traditions, and the importance of landscapes for collective memory, myths and folklore (Mitchell et al., 2009). One cultural landscape in Sweden is on the World Heritage list, the agricultural landscape of Southern Öland (an island in the Baltic Sea) containing large areas of semi-natural calcareous (alvar) grasslands.

However, this list only recognizes a small fraction of cultural landscapes. On a more basic level, and for many other cultural landscapes, most people probably associate heritage and tradition with activities which have occurred for a long time and which have left traces in the landscapes (biological, material, immaterial). These activities may, or may not, still be ongoing. Perceiving a direct relationship, for example across generations, is likely to promote recognition of cultural heritage. Being a formerly overlooked aspect of heritage, the Swedish National Heritage Board (2021) does now target biological cultural heritage as a specific objective for preservation (e.g., Ljung et al., 2015).

So how do people value landscapes with semi-natural grasslands grazed by livestock? In general terms, and using the ecosystem services (ES) framework, several studies have documented cultural ES derived from semi-natural grasslands maintained by livestock (e.g., Leroy et al., 2018; Bengtsson et al., 2019). A recent review (D'Ottavio et al., 2018) concluded that cultural ES from livestock grazing systems have generally been overlooked, despite findings suggesting that they are highly relevant for stakeholders. In fact, based on a global survey of perceptions of livestock in grassland systems, Leroy et al. (2018) concluded that cultural ES were the most valued by the respondents.

Focusing on semi-natural grasslands in Sweden, there are quite few studies available to answer the question how people value landscapes with semi-natural grasslands and livestock. Stenseke (2006) made surveys with farmers and concluded that, overall, semi-natural grasslands were highly valued. The most common values were associated with aspects of beauty (scenery) of the open and semi-open landscapes. Some farmers expressed a pride in maintaining these landscapes, and some, but not all, appreciated biodiversity (flower richness). Maintaining a "living landscape," i.e., where people can find means to live, was considered important. In another study based on surveys with farmers, Waldén and Lindborg (2018) stressed the importance of farmer's receiving support from conservation authorities and the local society. Broadening the picture to include not only the farmers themselves, landscape beauty and recreation have been documented as values (Andersson et al., 2015; Hahn et al., 2018). Land in Sweden outside private gardens and crop fields are accessible to all people, and many people enjoy a heterogeneous landscape with a mixture of semi-natural grasslands with livestock, grasslands and forests. These few studies may be complemented by information from publications not primarily aimed for researchers. Two recent books in Swedish (Ahlberg, 2020; Meyer von Bremen and Rundgren, 2020), both based on personal experience as well as interviews with people living in 


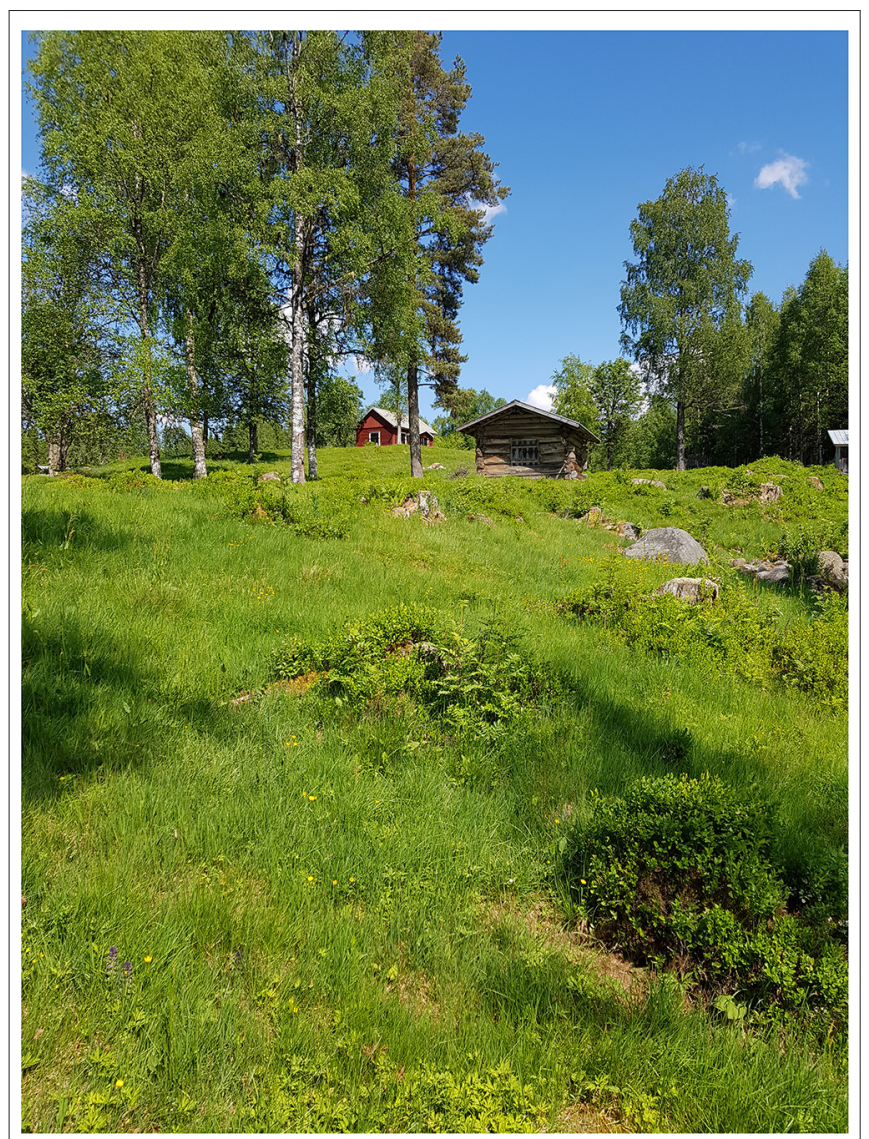

FIGURE 5 | A shieling (summer farm) from the Province of Värmland, Sweden. The photo was taken in late spring before livestock grazing started (Photo: The author).

these landscapes, provide a more complex picture of the values associated with keeping livestock on semi-natural grasslands. Aspects of human-animal connections, sense of place, a sense of meaning, appreciation of both being part of and continuing a long history of farming, all stand out as important values. These books thus come closer to the results of a comparative study of Sweden and Australia, which noted a fundamental difference between these countries in people's concepts of the humannature relationship (Saltzman et al., 2011). While agriculture with livestock in Australia was considered as a contrast to nature, people in Sweden often considered agriculture with livestock as part of nature (which was seen as something positive). Their conclusion was that this reflected the long history of dependence of livestock in Sweden. Perhaps such values have been partly overlooked in the survey studies reviewed above, as any questionnaire only receives answers reflecting the chosen questions. Indeed, a study conducted in Finland reports that farmers appreciate values relating to sense of place, identity and cultural heritage (Raatikainen and Barron, 2017). Another example comes from the few still remaining shielings (summer farms) in Sweden (Figure 5). These were until the beginning of the 20th century part of seasonal transhumance in forested and mountainous regions (Svensson, 2018), and today they engage people in maintaining and developing small-scale local production from livestock, for example dairy products as cheese (Bele et al., 2018; Rytkönen et al., 2018).

Except from biodiversity per se, and food (which is treated in the next section) the values associated with semi-natural grasslands, identified by research, revolve much around aspects of aesthetics, i.e., the beauty of these landscapes, appreciated both by those actually involved in livestock management, and by other people, including visitors. However, as mentioned, it seems possible that the importance of values associated with people's relations to the long history of livestock management has been underestimated. Chan et al. (2016) highlighted "relational values" as an addition to the dichotomy intrinsic-instrumental values, referring to "values relative to the meaningfulness of relationships." Relational values lie behind the concept "nature's contribution to people" used by IPBES (Intergovernmental science-Policy platform on Biodiversity and Ecosystem Services) (Díaz et al., 2018), and may serve as a conceptual framework for landscape management (Stenseke, 2018). From the viewpoint of governmental authorities, it is clear that the historical dimension is recognized (Swedish Board of Agriculture, 2019a; Swedish National Heritage Board, 2021). Whether this is just an "authorized heritage discourse" (Smith, 2006) or if it is truly based on people's perceptions, still remains an open question for future research. More research is needed to answer the question on how people in general value livestock grazing maintaining semi-natural grasslands.

\section{CURRENT AND POTENTIAL FOOD PRODUCTION IN SEMI-NATURAL GRASSLANDS}

In addition to the biodiversity and cultural heritage values reviewed above, livestock grazing in semi-natural grasslands also provides means to produce food (meat, dairy products) which by all standards must be regarded as sustainable. Livestock feed largely on biomass not accessible as food for humans, and there is no evidence suggesting that the current level of grazing depletes any resource pool. As livestock during the vegetation period graze outdoors this management also secures animal welfare.

In light of these positive effects, it is surprisingly difficult to gain detailed information of the contribution to Swedish food production from semi-natural grasslands, and therefore also on what the potential food production could be, given different future scenarios. Below follows an attempt to address this issue, based on various indirect sources.

In the introduction it was mentioned that there are about 400,000 hectares of semi-natural grasslands left in Sweden (Swedish Board of Agriculture, 2019a). However, the details of this statistics is somewhat more complex. Other sources present different figures, e.g., 450,000 hectares (Borgegård, 2015), and even 500,000 hectares (Berg et al., 2011). Around 200,000 hectares were assessed as having high biodiversity values by the Swedish Board of Agriculture (2019a). Curiously, on their homepage, the Swedish Board of Agriculture (2021a) mentions 
a higher figure, 250,000 hectares of semi-natural grasslands considered valuable. Semi-natural grasslands in Sweden have been surveyed since the late 1980's, and this information is compiled in a public database (TUVA Database, 2021). Larsson et al. (2020) reports that there are c. 330,000 hectares registered in this database, whereas there are in total c. 450,000 hectares of pasture land (including also grazed area not considered as semi-natural grassland) that receive subsidies for maintaining grazing. Using the search function in the database, with relaxed search criteria regarding current levels of management, records c. 187,000 hectares (TUVA Database, 2021). The average size of these semi-natural grasslands is c. 5 hectares, i.e., each site is quite small. As the size distribution is skewed (with some very large areas), the median size is even smaller, c. 2 hectares (Larsson et al., 2020).

A part of the explanation for these variable figures derives from the use of different criteria for defining semi-natural grasslands, and what distinguishes these from other grasslands grazed by livestock, for example former arable fields which have been transformed to pastures. Over time, such pastures may to some extent develop similar features regarding the flora as "true" semi-natural grasslands (Öster et al., 2009), so the distinction between what is, and what is not, a semi-natural grassland is sometimes diffuse. Some sources also include semi-natural grasslands that could potentially be restored. For example, Borgegård (2015) asserts that there are about 70,000 hectares currently lacking grazing.

In the following, and acknowledging that exact figures are elusive, it is assumed that the current food production is derived from between 250,000 and 400,000 hectares of semi-natural grasslands, but that this area could be increased given appropriate restoration and management. Borgegård (2015) suggest that a realistic goal may be 500,000 hectares.

Some of the food production from livestock grazing seminatural grasslands is local and small-scale. An example is meat and dairy products from still managed shielings (summer farms) (Rytkönen, 2016; Bele et al., 2018; Rytkönen et al., 2018). While maintaining these shielings undoubtedly contributes considerable values from a heritage viewpoint, they represent $<1 \%$ of the total area of semi-natural grasslands (TUVA Database, 2021), and thus a very small share of the total food production from semi-natural grasslands.

The by far most common product from semi-natural grasslands is meat, mainly from cattle, and less from sheep. Assuming that the relationships between these two sources of meat is the same for semi-natural grasslands as for meat consumption as a whole, sheep (lamb) represents c. 7\% of the production; the yearly (2020) total per capita consumption of meat in Sweden is $24.1 \mathrm{~kg}$, of which $22.5 \mathrm{~kg}$ is from cattle and $1.6 \mathrm{~kg}$ from sheep (Swedish Board of Agriculture, 2021b). Henceforth, "meat" refers to meat only from cattle and sheep.

There is no simple way to address the question of how large share of domestic meat production and consumption that derives from semi-natural grasslands. Larsson et al. (2020) estimated that the available semi-natural grasslands in Sweden potentially covers $36 \%$ of the land required for the current population of grazing livestock. If livestock were distributed equally among semi-natural grasslands and other pastures, this would suggest that semi-natural grasslands contribute to around a third of the domestic meat production. However, from the perspective of maintaining semi-natural grasslands, livestock may graze in the "wrong places" (Larsson et al., 2020). Much livestock production is conducted in landscapes where there are few semi-natural grasslands available and livestock may exclusively graze on former arable fields or strongly improved (fertilized) grasslands. Furthermore, most semi-natural grasslands are small (average c. 5 hectares), and there are logistical problems in transporting livestock to and from small semi-natural grassland sites. With regard to meat consumption we also have to consider that only $52 \%$ of all meat consumed in Sweden is produced domestically (Federation of Swedish Farmers, 2016), the rest is imported. Taken together, this leads to the conclusion that less than a third of the meat production, and thus less than a sixth of the meat consumption in Sweden derives from semi-natural grasslands. How much less is difficult to say, but an estimate may be in magnitude of around $20 \%$ of the production, and $10 \%$ of the consumption.

However, there is a potential to increase both production and consumption of meat produced on semi-natural grasslands. According to WWF (2012), increasing the total area of seminatural grasslands in Sweden to 500,000 hectares (as suggested by Borgegård, 2015), and managing these properly, would satisfy a yearly total per capita consumption of $10-20 \mathrm{~kg}$ meat (to be compared with the current per capita consumption of $24.1 \mathrm{~kg}$; Swedish Board of Agriculture, 2021b). As the current population of livestock is about three times higher than what would be required for grazing current semi-natural grasslands (Larsson et al., 2020), an increase to 500,000 hectares (from the current 250,000-400,000 hectares) would be possible without changing the total number of livestock. To guide consumers to select meat from semi-natural grasslands the products must be properly labeled. At present, there are several labels certifying to the consumer that meat sold in grocery stores comes from Swedish semi-natural grasslands (e.g., Borgegård, 2015).

Acknowledging the insecurity of these calculations, a general conclusion nevertheless stands out as robust. Semi-natural grasslands already contribute a significant share of the meat consumption in Sweden, and they may potentially contribute an increased share, if more land is managed as semi-natural grassland after restoration, and if consumers' willingness to buy these products increases. The exact figures may be difficult to specify, but that does not affect this general conclusion.

\section{SYNTHESIS AND CONCLUSIONS}

The major conclusion from this overview is that livestock grazing in Swedish semi-natural grasslands maintains coproduction of food, biological diversity and cultural heritage. Semi-natural grasslands have a long history of management and maintain a rich diversity of species. They are perceived as being associated with cultural heritage values, and although the exact amounts are uncertain, they give an important contribution to food production. Thus, there are positive relationships among these 


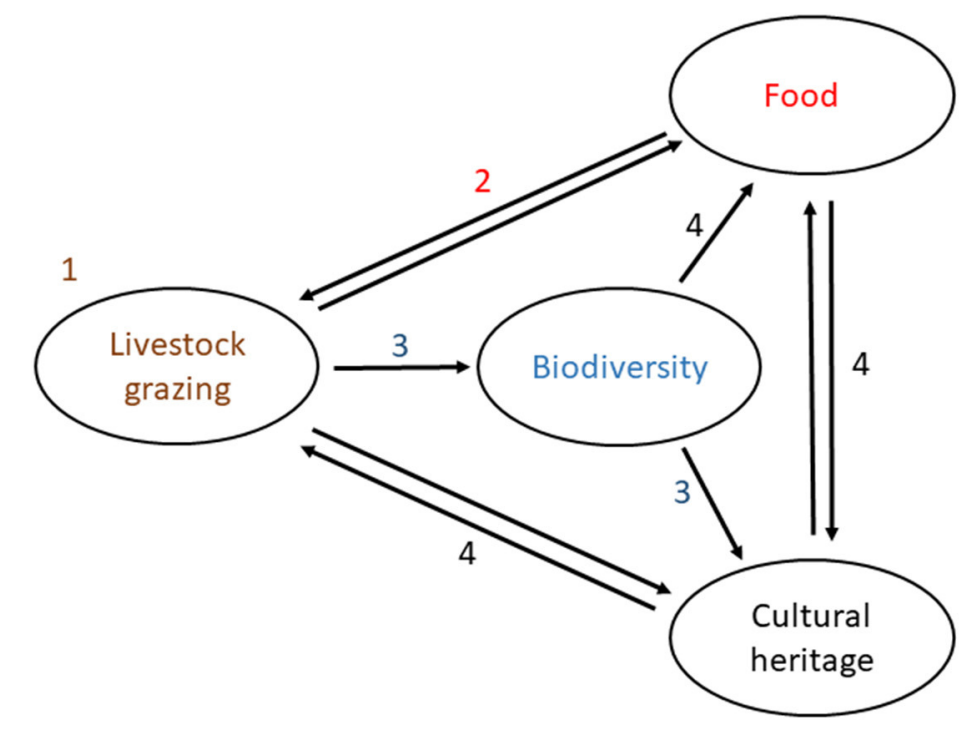

Constraints \& Challenges

1. Landscape structure and transport logistics

Farm economy: prices \& subsidies

Farmer's involvement and motivation

Implementing landscape perspective

2. Consumer's willingness to buy Distribution, labeling \& certification of products

3. Appropriate management regimes Implementing landscape perspective Re-negotiating 'authenticity'

Adapting goals to stakeholder perceptions

4. Information \& knowledge transfer Adapting goals to stakeholder perceptions

FIGURE 6 | Coproduction of food, biodiversity and cultural heritage, and a summary of main constraints and challenges. See the text for explanation.

aspects of semi-natural grasslands. At the same time, there are several constraints and challenges to overcome in order to maintain and promote these positive relationships.

Figure 6 visualizes the relationships, and summarizes the main constraints and challenges. Livestock grazing is the key to maintain semi-natural grasslands (Figure 4). A major constraint in maintaining and developing livestock grazing in these grasslands revolves around structural aspects in landscapes, for example that remaining semi-natural grasslands are small and isolated, and that there is often a poor fit between where livestock and semi-natural grasslands occur.

In addition to this "landscape structural" constraint, a major constraint for increasing, and even maintaining current meat production on semi-natural grasslands concerns the farmer's economy. This is first and foremost based on the willingness of consumers to buy the products from semi-natural grasslands, even though they have a higher price than alternative products. This constraint may in the long run be alleviated as there seems to be an increased willingness from consumers to buy "local" or "ecological” food (e.g., Feldmann and Hamm, 2015; Rytkönen et al., 2018). An increased willingness from consumers to buy the products will feedback positively to the extent of livestock grazing. To motivate consumers, labeling of the products is essential. As most consumers, especially urban people, are likely to be partly alienated from agriculture, information and transfer of knowledge is important. Secondly, farmer's economy depends on the level of subsidies, and it has been suggested that these subsidies would need to be raised in order to make meat production on semi-natural grasslands economically sustainable (Cederberg et al., 2018; Larsson et al., 2020). To this we must add the willingness of the farmer, in the first place, to choose keeping livestock on semi-natural grasslands. As several studies indicate, appropriate societal support and cooperation is essential to promote farmer's motivation and willingness to keep livestock in semi-natural grasslands (e.g., Stenseke, 2006; Borgegård, 2015; Raatikainen and Barron, 2017; Raatikainen, 2018; Waldén and Lindborg, 2018).

In order to reach the Swedish Environmental Goals "A rich diversity of plant and animal life" (Swedish Environmental Protection Agency, 2019) and "A varied agricultural landscape" (Swedish Board of Agriculture, 2019a), there is a need for a more holistic view of landscapes. In conservation biology this has been coined a "landscape perspective" (e.g., Lindborg et al., 2008). From the viewpoint of biodiversity, this perspective implies that focus cannot be only on specific objects (for example a small nature reserve) in landscapes, but one has to consider the spatial dynamics of species incorporating dispersal routes and creation of new suitable habitats beyond the current occurrences of species. It is still unsettled what is the best management regime for maintaining biodiversity in semi-natural grasslands; possibly there might even be trade-offs in optimal management regimes for different taxa. Maintaining heterogeneity and variation in landscapes is however undoubtedly beneficial for biodiversity. A landscape perspective also concerns the people actually living in the landscapes, for example their opportunities for jobs and recreation, a "living landscape." Farmer's involvement in all societal actions is essential. For both inhabitants and visitors, landscape aesthetics is important. This calls for striving toward landscape multifunctionality (e.g., Gibon, 2005; Barron et al., 2021), also promoting relational values associated with biodiversity and cultural heritage (e.g., Díaz et al., 2018; Stenseke, 2018).

Biologists may need to be more flexible regarding what is an authentic semi-natural grassland; also less speciesrich grasslands, for example former arable fields which have developed toward being similar to semi-natural grasslands should be appreciated, as this increases the likelihood that farmers maintain livestock management. The mechanisms 
behind maintaining a high species diversity in semi-natural grasslands are fairly well-known (see the section Biodiversity in semi-natural grasslands). As has been shown in many studies, these mechanisms are associated with the historical management. However, maintaining grazing, even though this is conducted in a way adapted to the modern society, will promote and maintain at least the major part of this biodiversity. For example, one way to improve farmer's profitability is to merge semi-natural grassland fragments with adjacent pastures (Holmström et al., 2018) even if this potentially compromises the authenticity (in a strict sense) of the semi-natural grasslands. Thus, in order to reduce the risk that grazing management is abandoned it may be necessary to abandon a too restrictive view of what kind of grasslands are valuable to preserve.

It has been recognized that modern landscapes include novel (or hybrid) ecosystems which may be valuable for biodiversity (e.g., Hobbs et al., 2009; Kasari et al., 2016), and this is also true for biodiversity associated with seminatural grasslands (Berg et al., 2011; Eriksson, 2016). A similar reasoning holds for aspects of cultural heritage, which should be seen as something continuously produced and subjected to change. As remarked above, perceptions of cultural values are continuously changing. For example, one should encourage new ways to manage and engage in semi-natural grasslands by entrepreneurship and enterprises, partly relying on traditions and partly on modernity (e.g.,

\section{REFERENCES}

Ahlberg, M. (2020). Levande Landskap: En Resa till Framtidens Jordbruk. Bjuråker: Balders Förlag. (In Swedish).

Andersson, E., Nykvist, B., Malinga, R., Jaramillo, F., and Lindborg, R. (2015). A social-ecological analysis of ecosystem services in two different farming systems. Ambio 44, S102-S112. doi: 10.1007/s13280-014-0603-y

Antrop, M. (2005). Why landscapes of the past are important for the future. Landsc. Urban Plan. 70, 21-34. doi: 10.1016/j.landurbplan.2003.10.002

Auestad, I., Rydgren, K., and Austad, I. (2011). Road verges: potential refuges for declining grassland species despite remnant vegetation dynamics. Ann. Bot. Fenn. 48, 289-303. doi: 10.5735/085.048.0401

Auffret, A. G., and Cousins, S. A. O. (2018). Land uplift creates important meadow habitat and a potential original niche for grassland species. Proc. R. Soc. B 285:20172349. doi: 10.1098/rspb.2017.2349

Aune, S., Bryn, A., and Hovstad, K. A. (2018). Loss of semi-natural grassland in a boreal landscape: impacts of agricultural intensification and abandonment. J. Land Use Sci. 13, 375-390. doi: 10.1080/1747423X.2018.1539779

Bar-On, Y. M., Phillips, R., and Milo, R. (2018). The biomass distribution of Earth. Proc. Natl. Acad. Sci. U.S.A 115, 6506-6511. doi: 10.1073/pnas.1711842115

Barron, L. J. R., Andonegi, A., Gamboa, G., Garmendia, E., García, O., Aldai, N., et al. (2021). Sustainability assessment of pasture-based dairy sheep systems: a multidisciplinary and multiscale approach. Sustainability 13:3994. doi: $10.3390 /$ su13073994

Bele, B., Norderhaug, A., and Sickel, H. (2018). Localized agri-food systems and biodiversity. Agriculture 8:22. doi: 10.3390/agriculture8020022

Bengtsson, J., Bullock, J. M., Egoh, B., Everson, C., O’Connor, T., O’Farrell, P. J., et al. (2019). Grasslands - more important for ecosystem services than you might think. Ecosphere 10:e02582. doi: 10.1002/ecs2.2582

Berg, Å., Ahrn,é, K., Öckinger, E., Svensson, R., and Söderström, B. (2011). Butterfly distribution and abundance is affected by variation in the Swedish forest-farmland landscape. Biol. Conserv. 144, 2819-2831. doi: 10.1016/j.biocon.2011.07.035
Olsson, 2008; Borgegård, 2015; Rytkönen et al., 2018; Svensson, 2018).

In conclusion, recognizing the long history of humanlivestock interactions as it is played out in the modern society as coproduction relationships has a great potential to promote future sustainable food production as well as biodiversity and cultural heritage in Swedish semi-natural grasslands.

\section{DATA AVAILABILITY STATEMENT}

The original contributions presented in the study are included in the article/supplementary materials, further inquiries can be directed to the corresponding author/s.

\section{AUTHOR CONTRIBUTIONS}

The author confirms being the sole contributor of this work and has approved it for publication.

\section{ACKNOWLEDGMENTS}

I am grateful to two reviewers for comments on the manuscript, to L. Glav Lundin for assistance in compiling information on livestock production in semi-natural grasslands, and to $\mathrm{O}$. Jennersten for kind permission to use some of his photographs.

Berglund, B. E., Gaillard, M.-J., Björkman, L., and Persson, T. (2008). Long term changes in floristic diversity in southern Sweden: palynological richness, vegetation dynamics and land-use. Veg. Hist. Archaeobot. 17, 573-583. doi: 10.1007/s00334-007-0094-x

Berglund, B. E., Kitigawa, J., Lagerås, P., Nakamura, K., Sasaki, N., and Yasuda, Y. (2014). Traditional farming landscapes for sustainable living in Scandinavia and Japan: global revival through the Satoyama initiative. Ambio 43, 559-578. doi: 10.1007/s13280-014-0499-6

Bignal, E. M., and McCracken, D. I. (1996). Low-intensity farming systems in the conservation of the countryside. J. Appl. Ecol. 33, 413-424. doi: $10.2307 / 2404973$

Blondel, J. (2006). The 'design' of Mediterranean landscapes: a millennial story of humans and ecological systems during the historic period. Hum. Eco. 34, 713-729. doi: 10.1007/s10745-006-9030-4

Boles, O. J. C., and Lane, P. J. (2016). The green, green grass of home: an archaeo-ecological approach to pastoralist settlement in central Kenya. Azania: Archaeol. Res. Afr. 51, 507-530. doi: 10.1080/0067270X.2016.1249587

Borgegård, S.-O. (2015). WWFs Naturbetesprojekt: Långsiktiga effekter av 25 års arbete. World Wildlife Fund. Available online at: https://wwwwwfse.cdn. triggerfish.cloud/uploads/2019/01/wwfs-naturbetesprojekt-2015-rapport-143890.pdf (accessed October 11, 2021).

Braaksma, P. J., Jacobs, M. H., and van der Zande, A. N. (2016). The production of local landscape heritage: A case study in the Netherlands. Landsc. Res. 41, 64-78. doi: 10.1080/01426397.2015.1045465

Bruun, H. H., and Fritzbøger, B. (2002). The past impact of livestock husbandry on dispersal of plant seeds in the landscape of Denmark. Ambio 31, 425-431. doi: 10.1579/0044-7447-31.5.425

Cederberg, C., Henriksson, M., and Rosenqvist, H. (2018). Ekonomi Och Ekosystemtjänster i Gräsbaserad Mjölk- Och Nötköttsproduktion. Göteborg: Chalmers Tekniska Högskola.

Chan, K., Balvanera, P., Benessaiah, K., Chapman, M., Díaz, S., Gómez-Baggethun, E., et al. (2016). Why protect nature? Rethinking values and the environment. Proc. Natl. Acad. Sci. U.S.A. 113, 1462-1465. doi: 10.1073/pnas. 1525002113 
Cousins, S. A. O. (2001). Analysis of land-cover transitions based on 17th and 18th century cadastral maps and aerial photographs. Landsc. Ecol. 16, 41-54. doi: 10.1023/A:1008108704358

Cousins, S. A. O. (2009). Landscape history and soil properties affect grassland decline and plant species richness in rural landscapes. Biol. Conserv. 142, 2752-2758. doi: 10.1016/j.biocon.2009.07.001

Cousins, S. A. O., Auffret, A. G., Lindgren, J., and Tränk, L. (2015). Regionalscale land-cover change during the $20^{\text {th }}$ century and its consequences for biodiversity. Ambio 44, S17-S27. doi: 10.1007/s13280-014-0585-9

Cousins, S. A. O., and Eriksson, O. (2002). The influence of management history and habitat on plant species richness in a rural hemiboreal landscape. Landsc. Ecol. 17, 517-529. doi: 10.1023/A:1021400513256

Cusser, S., Neff, J. L., and Jha, S. (2018). Land-use history drives contemporary pollinator community similarity. Landsc. Ecol. 33, 1335-1351. doi: 10.1007/s10980-018-0668-2

Dahlström, A., Cousins, S. A. O., and Eriksson, O. (2006). The history (16202003) of land use, people and livestock, and the relationship to present plant species diversity in a rural landscape in Sweden. Environ. Hist. 12, 191-212. doi: 10.3197/096734006776680218

Díaz, S., Pascual, U., Stenseke, M., Martín-López, B., Watson, R. T., Molnár, Z., et al. (2018). Assessing nature's contributions to people. Science 359, 270-272. doi: 10.1126/science.aap8826

Diekmann, M., Dupré, C., and van der Maarel, E. (2004). Fine-scale species association in alvar limestone grassland. Nord. J. Bot. 23, 115-128. doi: 10.1111/j.1756-1051.2003.tb00373.x

Dobrovodská, M., Kanka, R., David, S., Kollár, J., and Štefunková, D. (2019). Assessment of the biocultural value of traditional agricultural landscape on a plot-by-plot level: case studies from Slovakia. Biodiv. Conserv. 28, 2515-2645. doi: 10.1007/s10531-019-01784-X

D’Ottavio, P., Francioni, M., Trozzo, L., Sedić, E., Budimir, K., Avanzolini, P., et al. (2018). Trends and approaches in the analysis of ecosystem services provided by grazing systems: a review. Grass Forage Sci. 73, 15-25. doi: 10.1111/gfs.12299

Dover, J. W., Spencer, S., Collins, S., Hadjigeorgiou, I., and Rescia, A. (2011). Grassland butterflies and low intensity farming in Europe. J. Insect Conserv. 15, 129-137. doi: 10.1007/s10841-010-9332-0

Eide, W., Ahrné, K., Bjelke, U., Nordström, S., Ottosson, E., Sandström, J., et al. (2020). Tillstånd och trender för arter och deras livsmiljöer: rödlistade arter $i$ Sverige 2020. SLU ArtDatabanken rapporterar 24. Uppsala: SLU ArtDatabanken.

Ekstam, U., and Forshed, N. (1992). Om hävden upphör. Stockholm: Naturvårdsverket.

Emanuelsson, U. (2009). The Rural Landscape of Europe: How Man Has Shaped European Nature. Stockholm: The Swedish Research Council Formas.

Eriksson, Å., and Eriksson, O. (1997). Seedling recruitment in semi-natural pastures: the effects of disturbance, seed size, phenology and seed bank. Nord. J. Bot. 17, 469-482. doi: 10.1111/j.1756-1051.1997.tb00344.x

Eriksson, O. (2013). Species pools in cultural landscapes: niche construction, ecological opportunity and niche shifts. Ecography 36, 403-413. doi: 10.1111/j.1600-0587.2012.07913.x

Eriksson, O. (2016). Historical and current niche construction in an anthropogenic biome: old cultural landscapes in southern Scandinavia. Land 5:42. doi: 10.3390/land5040042

Eriksson, O. (2018). What is biological cultural heritage and why should we care about it? An example from Swedish rural landscapes and forests. Nat. Conserv. 28, 1-32. doi: 10.3897/natureconservation.28. 25067

Eriksson, O. (2020). Origin and development of managed meadows in Sweden: A review. Rural Landsc. Soc. Environ. Hist. 7, 1-23. doi: 10.16993/rl.51

Eriksson, O. (2021). The importance of traditional agricultural landscapes for preventing species extinctions. Biodiv. Conserv. 30, 1341-1357. doi: 10.1007/s10531-021-0 2145-3

Eriksson, O., Arnell, M., and Lindholm, K.-J. (2021). Historical ecology of Scandinavian infield systems. Sustainability 13:817. doi: 10.3390/su13020817

Eriksson, O., Bolmgren, K., Westin, A., and Lennartsson, T. (2015). Historic hay cutting dates from Sweden 1873-1951 and their implications for conservation management of species-rich meadows. Biol. Conserv. 184, 100-1007. doi: 10.1016/j.biocon.2015.01.012
Eriksson, O., and Cousins, S. A. O. (2014). Historical landscape perspectives on grasslands in Sweden and the Baltic region. Land 3, 300-321. doi: 10.3390/land3010300

Eriksson, O., Wikström, S., Eriksson, Å., and Lindborg, R. (2006). Species-rich Scandinavian grasslands are inherently open to invasion. Biol. Invasions 8, 355-363. doi: 10.1007/s10530-004-4720-6

Federation of Swedish Farmers (2016). LRF: Handlingsplan Nöt - För att öka svensk nötköttsproduktion. Available online at: https://www.lrf.se/sok/?query= Handlingsplan\$+\$N\%C3\%B6t (accessed October 11, 2021).

Feldmann, C., and Hamm, U. (2015). Consumers' perceptions and preferences for local food: a review. Food Qual. Preference 40, 152-164. doi: 10.1016/j.foodqual.2014.09.014

Franzén, D. (2001). The role of species richness for recruitment in a seminatural grassland. Oikos 95, 409-415. doi: 10.1034/j.1600-0706.2001.950305.x

Gadd, C.-J. (2011). “The agricultural revolution in Sweden 1700-1870,” in The Agrarian History of Sweden from 4000 BC to AD 2000, eds J. Myrdal and M. Morell (Lund: Nordic Academic Press) 118-164.

Gerber, P. J., Mottet, A., Opio, C. I., Falcucci, A., and Teillard, F. (2015). Environmental impacts of beef production: Review of challenges and perspectives for durability. Meat Sci. 109, 2-12. doi: 10.1016/j.meatsci.2015.05.013

Gibon, A. (2005). Managing grassland for production, the environment and the landscape: challenges at the farm and the landscape level. Livest. Prod. Sci. 96, 11-31. doi: 10.1016/j.livprodsci.2005.05.009

Gill, J. L. (2013). Ecological impacts of the late Quaternary megaherbivore extinctions. New Phytol. 201, 1163-1169. doi: 10.1111/nph.12576

Glav Lundin, L., and Eriksson, O. (2021). The decline of Gentianella campestris: three decades of population development of an endangered grassland plant in Sweden. Nord. J. Bot. 39:e03007. doi: 10.1111/njb.03007

Grime, J. P. (1979). Plant Strategies \& Vegetation Processes. Chichester: John Wiley \& Sons.

Grubb, P. J. (1977). Maintenance of species-richness in plant communities: Importance of regeneration niche. Biol. Rev. 52, 107-145. doi: 10.1111/j.1469-185X.1977.tb01347.x

Gustavsson, E., Lennartsson, T., and Emanuelsson, M. (2007). Land use more than 100 years ago explains current grassland plant diversity in a Swedish agricultural landscape. Biol. Conserv. 138, 47-59. doi: 10.1016/j.biocon.2007.04.004

Hahn, T., Heinrup, M., and Lindborg, R. (2018). Landscape heterogeneity correlates with recreational values: a case study from Swedish agricultural landscapes and implications for policy. Landsc. Res. 43, 696-707. doi: 10.1080/01426397.2017.1335862

Helm, A., Hanski, I., and Pärtel, M. (2006). Slow response of plant species richness to habitat loss and fragmentation. Ecol. Lett. 9, 72-77. doi: 10.1111/j.1461-0248.2005.00841.x

Herrero, M., Havlík, P., Valin, H., Notenbaert, A., Rufino, M. C., Thornton, P. K., et al. (2013). Biomass use, production, feed efficiencies, and greenhouse gas emissions from global livestock systems. Proc. Natl. Acad. Sci. U.S.A. 110, 20888-20893. doi: 10.1073/pnas.1308149110

Herzon, I., Raatikainen, K. J., Wehn, S., Rusina, S., Helm, A., Cousins, S. A. O., et al. (2021). Semi-natural habitats in boreal Europe: a rise of a social-ecological research agenda. Ecol. Soc. 26:13. doi: 10.5751/ES-12313260213

Hobbs, R. J., Higgs, E., and Harris, J. A. (2009). Novel ecosystems: implications for conservation and restoration. Trends Ecol. Evol. 24, 599-605. doi: 10.1016/j.tree.2009.05.012

Hobsbawn, E. (1983). "Introduction: Inventing traditions," in The Inventions of Traditions, eds E. Hobsbawn and T. Ranger (Cambridge: Cambridge Univ. Press) 1-14.

Holmström, K., Hessle, A., Andersson, H., and Kumm, K.-I. (2018). Merging small scattered pastures into large pasture-forest mosaics can improve profitability in Swedish suckler-based beef production. Land 7:58. doi: 10.3390/land702 0058

Johansen, L., Westin, A., Wehn, S., Iuga, A., Ivascu, C. M., Kallioniemi, E., et al. (2019). Traditional semi-natural grassland management with heterogeneous mowing times enhances flower resources for pollinators in agricultural landscapes. Global Ecol. Conserv. 18:e00619. doi: 10.1016/j.gecco.2019. e00619 
Johansson, L. J., Hall, K., Prentice, H. C., Ihse, M., Reitalu, T., Sykes, M., et al. (2008). Semi-natural grassland continuity, long-term land-use change and plant species richness in an agricultural landscape on Öland, Sweden. Landsc. Urban Plan. 84, 200-211. doi: 10.1016/j.landurbplan.2007.08.001

Johansson, V. A., Cousins, S. A. O., and Eriksson, O. (2011). Remnant populations and plant functional traits in abandoned semi-natural grasslands. Folia Geobot. 46, 165-179. doi: 10.1007/s12224-010-9071-8

Johnson, C. N. (2009). Ecological consequences of Late Quaternary extinctions of megafauna. Proc. R. Soc. B 276, 2509-2519. doi: 10.1098/rspb.2008.1921

Kardell, Ö. (2016). Swedish forestry, forest pasture grazing by livestock, and game browsing pressure since 1900. Environ. Hist. 22, 561-587. doi: 10.3197/096734016X14727286515817

Kasari, L., Saar, L., de Bello, F., Takkis, K., and Helm, A. (2016). Hybrid ecosystems can contribute to local biodiversiy conservation. Biodiv. Conserv. 25, 3023-3041. doi: 10.1007/s10531-016-1218-3

Kristiansen, K. (2007). "Eurasian transformations: mobility, ecological change, and the transmission of social institutions in the third millenium and early second millenium BCE," in The World System and the Earth System: Global Socioenvironmental Change and Sustainability since the Neolithic, eds A. Hornborg and C. Crumley (Walnut Creek: Left Coast Press) 149-162.

Larsson, C., Boke Olén, N., and Brady, M. (2020). Naturbetesmarkernas framtid en fråga om lönsamhet. Agrifood Rapport.

Lennartsson, T., Westin, A., Iuga, A., Jones, E., Madry, S., Murray, S., et al. (2016). The meadow is the mother of the field. Comparing transformations in hay production in three European agroecosystems. Martor 21, 103-126.

Lenoir, L., and Lennartsson, T. (2010). Effects of timing of grazing on arthropod communities in semi-natural grasslands. J. Insect Sci. 10:60. doi: $10.1673 / 031.010 .6001$

Leroy, G., Hoffmann, I., From, T., Hiemstra, S. J., and Gandini, G. (2018). Perception of livestock ecosystem services in grazing areas. Animal 12, 2627-2638. doi: 10.1017/S1751731118001027

Lindborg, R., Bengtsson, J., Berg, A., Cousins, S. A. O., Eriksson, O., Gustafsson, T., et al. (2008). A landscape perspective on conservation of semi-natural grasslands. Agric. Ecosyst. Environ. 125, 213-222. doi: 10.1016/j.agee.2008.01.006

Lindborg, R., and Eriksson, O. (2004). Historical landscape connectivity affects present plant species diversity. Ecology 85, 1840-1845. doi: 10.1890/04-0367

Ljung, T., Lennartsson, T., and Westin, A. (2015). Inventering av biologiskt kulturarv. Stockholm: Riksantikvarieämbetet.

MacDougall, A. S., McCune, J. L., Eriksson, O., Cousins, S. A. O., Pärtel, M., Firn, J., et al. (2018). The Neolithic plant invasion hypothesis: the role of preadaptation and disturbance in grassland invasion. New Phytol. 220, 94-103. doi: $10.1111 / \mathrm{nph} .15285$

Mäkeläinen, S., Hario, A., Heikkinen, R. K., Herzon, I., Kuussaari, M., Lepikk,ö, K., et al. (2019). Coincidence of High Nature Value farmlands with bird and butterfly diversity. Agric. Ecosyst. Environ. 269, 224-233. doi: 10.1016/j.agee.2018.09.030

Manton, M., and Angelstam, P. (2018). Defining benchmarks for restoration of green infrastructure: a case study combining the historical range of variability of habitat and species' requirements. Sustainability 10:326. doi: $10.3390 /$ su10020326

Marteinsdóttir, B., and Eriksson, O. (2014). Trait-based filtering from the regional species pool into local grassland communities. J. Plant Ecol. 7, 347-355. doi: $10.1093 /$ jpe/rtt032

McClure, S. B. (2015). The pastoral effect: Niche construction, domestic animals, and the spread of farming in Europe. Curr. Anthropol. 56, 901-910. doi: $10.1086 / 684102$

Mehrabi, Z., Ellis, E. C., and Ramankutty, N. (2018). The challenge of feeding the world while conserving half the planet. Nat. Sustainab. 1, 409-412. doi: 10.1038/s41893-018-0119-8

Meyer von Bremen, A.-H., and Rundgren, G. (2020). Kornas planet: Om jordens och mångfaldens beskyddare. Stockholm: Ordfront.

Milberg, P., Bergman, K.-O., Cronwall, E., Eriksson, Å. I., Glimskär, A., Islamovic, A., et al. (2016). Flower abundance and vegetation height as predictors for nectar-feeding insect occurrence in Swedish semi-natural grasslands. Agric. Ecosyst. Environ. 230, 47-54. doi: 10.1016/j.agee.2016. 05.029
Milberg, P., Bergman, K.-O., Jonason, D., Karlsson, J., and Westerberg, L. (2019). Land-use history influence the vegetation in coniferous production forests in southern Sweden. Forest Ecol. Manag. 440, 23-30. doi: 10.1016/j.foreco.2019.03.005

Millard, J., Outhwaite, C. L., Kinnersley, R., Freeman, R., Gregory, R. D., Adedoja, O., et al. (2021). Global effects of land-use intensity on local pollinator biodiversity. Nat. Comm. 12:2902. doi: 10.1038/s41467-021-23228-3

Mitchell, N., Rössler, M., and Tricaud, P.-M. (2009). World Heritage Cultural Landscapes: A Handbook for Conservation and Management. Paris: UNESCO World Heritage Centre.

Mottet, A., de Haan, C., Falcucci, A., Tempio, G., Opio, C., and Gerber, P. (2017). Livestock: On our plates or eating at our table? A new analysis of the feed/food debate. Glob. Food Secur. 14, 1-8. doi: 10.1016/j.gfs.2017.01.001

O'Dwyer, R., Marquer, L., Trondman, A.-K., and Jönsson, A. M. (2021). Spatially continuous land-cover reconstructions through the Holocene in southern Sweden. Ecosystems 24, 1450-1467. doi: 10.1007/s10021-020-00594-5

Olsson, R. (2008). Mångfaldsmarker: Naturbetesmarker - en värdefull resurs. Uppsala: HagmarksMistra/CBM.

Öster, M., Ask, K., Cousins, S. A. O., and Eriksson, O. (2009). Dispersal and establishment limitation reduces the potential for successful restoration of semi-natural grassland communities on former arable fields. J. Appl. Ecol. 46, 1266-1274. doi: 10.1111/j.1365-2664.2009.01721.x

Phalan, B., Onial, M., Balmford, A., and Green, R. E. (2011). Reconciling food production and biodiversity conservation: land sharing and land sparing compared. Science 333, 1289-1291. doi: 10.1126/science.1208742

Plieninger, T., Hartel, T., Martín-López, B., Beaufoy, G., Bergmeier, E., Kirby, K., et al. (2015). Wood-pastures of Europe: geographic coverage, social-ecological values, conservation management, and policy implications. Biol. Conserv. 190, 70-79. doi: 10.1016/j.biocon.2015.05.014

Pykälä, J. (2004). Cattle grazing increases plant species richness of most species trait groups in mesic semi-natural grasslands. Plant Ecol. 175, 217-226. doi: 10.1007/s11258-005-0015-y

Quested, H., Eriksson, O., Fortunel, C., and Garnier, E. (2007). Plant traits relate to whole-community litter quality and decomposition following land use change. Funct. Ecol. 21, 1016-1026. doi: 10.1111/j.1365-2435.2007.01324.x

Raatikainen, K. J. (2018). The importance of engaging local people in landscape management - experiences from an EU-project. Landsc. Online 57, 1-22. doi: 10.3097/LO.201857

Raatikainen, K. J., and Barron, E. S. (2017). Current agri-environmental policies dismiss varied perceptions and discourses on management of traditional rural biotopes. Land Use Policy 69, 564-576. doi: 10.1016/j.landusepol.2017.10.004

Roberts, N., Fyfe, R. M., Woodbridge, J., Gaillard, M.-J., Davis, B. A. S., Kaplan, J. O., et al. (2018). Europe's lost forests: a pollen-based synthesis for the last 11,000 years. Sci. Rep. 8:716. doi: 10.1038/s41598-017-18646-7

Rook, A. J., Dumont, B., Isselstein, J., Osoro, K., WallisDeVries, M. F., Parente, G., et al. (2004). Matching type of livestock to desired biodiversity outcomes in pastures - a review. Biol. Conserv. 119, 137-150. doi: 10.1016/j.biocon.2003.11.010

Rössler, M. (2006). World heritage cultural landscapes: A UNESCO flagship programme 1992-2006. Landsc. Res. 4, 333-353. doi: $10.1080 / 01426390601004210$

Rotherham, I. D. (2015). Bio-cultural heritage and biodiversity: emerging paradigms in conservation and planning. Biodiv. Conserv. 24, 3405-3429. doi: $10.1007 /$ s10531-015-1006-5

Rowley-Conwy, P. (2011). Westward ho! The spread of agriculture from central Europe to the Atlantic. Curr. Anthropol. 52, S431-S451. doi: 10.1086/658368

Rydin, H., Diekmann, M., and Hallingbäck, T. (1997). Biological characteristics, habitat associations, and distribution of macrofungi in Sweden. Conserv. Biol. 11, 628-640. doi: 10.1046/j.1523-1739.1997. 96437.x

Rytkönen, P. (2016). Local resources, foreign influences, value creation, tradition and modernity. The case of a local agro-food system in Jämtland, Sweden. Cult. Hist. Digit. J. 5:e009. doi: 10.3989/chdj.2016.009

Rytkönen, P., Bonow, M., Girad, C., and Tunón, H. (2018). Bringing the consumer back in - The motives, perceptions, and values behind consumeras and rural tourists decision to buy local and localized artisan food - a Swedish example. Agriculture 8:58. doi: 10.3390/agriculture8040058 
Saltzman, K., Head, L., and Stenseke, M. (2011). Do cows belong in nature? The cultural basis of agriculture in Sweden and Australia. J. Rural Stud. 27, 54-62. doi: 10.1016/j.jrurstud.2010.09.001

Sjörs, H. (1999). The background: geology, climate and zonation. Acta Phytogeogr. Suec. $84,5-14$.

Smith, M. (2006). The Uses of Heritage. London: Routledge. doi: $10.4324 / 9780203602263$

Springmann, M., Clark, M., Mason-D’Croz, D., Wiebe, K., Bodirsky, B. L., Lassaletta, L., et al. (2018). Options for keeping the food limits within environmental limits. Nature 562, 519-525. doi: 10.1038/s41586-018-0594-0

Stenseke, M. (2006). Biodiversity and the local context: linking seminatural grasslands and their future use to social aspects. Environ. Sci. Policy 9, 350-359. doi: 10.1016/j.envsci.2006.01.007

Stenseke, M. (2016). Integrated landscape management and the complicating issue of temporality. Landsc. Res. 41, 199-211. doi: 10.1080/01426397.2015.1135316

Stenseke, M. (2018). Connecting 'relational values' and relational landscape approaches. Curr. Opin. Sust. 35, 82-88. doi: 10.1016/j.cosust.2018.10.025

Svenning, J.-C. (2002). A review of natural vegetation openness in north-western Europe. Biol. Conserv. 104, 133-148. doi: 10.1016/S0006-3207(01)00162-8

Svensson, E. (2018). "The Scandinavian shieling: Between innovation and tradition," in Historical Archaeologies of Transhumance across Europe, eds E. Costello and E. Svensson (London: Routledge) 15-27. doi: 10.4324/9781351213394-2

Svensson, E., Amundsen, H. R., Holm, I., Hulling, H., Johansson, A., Löfgren, J., et al. (2018). Empowering marginal lifescapes: The heritage of crofters in between the past and the present. Int. J. Heritage Stud. 24, 17-34. doi: 10.1080/13527258.2017.1362579

Swedish Board of Agriculture (2019a). Ett rikt odlingslandskap. Available online at: https://www.sverigesmiljomal.se/miljomalen/ett-rikt-odlingslandskap/ (accessed October 7, 2021)

Swedish Board of Agriculture (2019b). Plan för odlingslandskapets biologiska mångfald. Available online at: https://www2.jordbruksverket.se/download/18. 36d57baa168c704154d46f04/1549611543321/ra19_1.pdf (accessed October 7, 2021).

Swedish Board of Agriculture (2021a). Available online at: https://jordbruksverket. se/vaxter/odling/biologisk-mangfald/angs--och-betesmarker (accessed October 12, 2021).

Swedish Board of Agriculture (2021b). Available online at: https://jordbruksverket. se/mat-och-drycker/hallbar-produktion-och-konsumtion-av-mat/ konsumtion-av-kott (accessed October 11, 2021).

Swedish Environmental Protection Agency (2019). Ett rikt växt- och djurliv. Available online at: https://www.sverigesmiljomal.se/miljomalen/ett-riktvaxt--och-djurliv/ (accessed October 7, 2021).

Swedish National Heritage Board (2021). Available online at: https:/www.raa.se/ kulturarv/landskap/biologiskt-kulturarv/ (accessed October 8, 2021).

TUVA Database (2021). Available online at: https://jordbruksverket.se/tuva (accessed October 11, 2021)

Van der Plas, G. W., De Cort, G., Petek-Sargeant, N., Wuytack, T., Colombaroli, D., Lane, P. J., et al. (2019). Distinct phases of natural landscape dynamics and intensifying human activity in the central Kenya Rift Valley during the past 1300 years. Quater. Sci. Rev. 218, 91-106. doi: 10.1016/j.quascirev.2019.06.009
Veen, P., Jefferson, R., de Smidt, J., and van der Straaten, J. (2009). Grasslands in Europe of High Nature Value. Zeist: KNNV Publishing. doi: 10.1163/9789004278103

Waldén, E., and Lindborg, R. (2016). Long term positive effect of grassland restoration on plant diversity - success or not? PLoS ONE 11, e0155836. doi: 10.1371/journal.pone.0155836

Waldén, E., and Lindborg, R. (2018). Facing the future for grasssland restoration - what about the farmers? J. Environ. Manag. 227, 305-312. doi: 10.1016/j.jenvman.2018.08.090

Wanner, H., Beer, J., Bütikofer, J., Crowley, T. J., Cubasch, U., Flückiger, J., et al. (2008). Mid- to late Holocene climate change: an overview. Q. Sci. Rev. 27, 1791-1828. doi: 10.1016/j.quascirev.2008.06.013

Widgren, M. (2012). Climate and causation in the Swedish Iron Age: learning from the present to understand the past. Geograf. Tidskr. - Danish J. Geogr. 112, 126-134. doi: 10.1080/00167223.2012.741886

Willett, W., Rockström, J., Loken, B., Springmann, M., Land, T., Vermeulen, S., et al. (2019). Food in the anthropocene: the EAT-Lancet commission on healthy diets from sustainable food systems. Lancet 393, 447-492. doi: 10.1016/S0140-6736(18)31788-4

Wilson, J. B., Peet, R. K., Dengler, J., and Pärtel, M. (2012). Plant species richness: the world records. J. Veg. Sci. 23, 796-802. doi: 10.1111/j.1654-1103.2012.01400.x

WWF (2012). Naturbetesmarker: en resurs som måste användas. Available online at: https://www.wwf.se/dokument/naturbetesmarker-en-resurs-sommaste-anvandas/ (accessed October 11, 2021).

Yi, S., Wu, N., Luo, P., Wang, Q., Shi, F., Zhang, Q., et al. (2008). Agricultural heritage in disintegration: trends of agropastoral transhumance on the southeast Tibetan Plateau. Int. J. Sust. Develop. World Ecol. 15, 273-282. doi: 10.3843/SusDev. 15.3:10

Zeder, M. (2011). The origins of agriculture in the Near East. Curr. Anthropol. 52, S221-S235. doi: 10.1086/65 9307

Conflict of Interest: The author declares that the research was conducted in the absence of any commercial or financial relationships that could be construed as a potential conflict of interest.

Publisher's Note: All claims expressed in this article are solely those of the authors and do not necessarily represent those of their affiliated organizations, or those of the publisher, the editors and the reviewers. Any product that may be evaluated in this article, or claim that may be made by its manufacturer, is not guaranteed or endorsed by the publisher.

Copyright (c) 2022 Eriksson. This is an open-access article distributed under the terms of the Creative Commons Attribution License (CC BY). The use, distribution or reproduction in other forums is permitted, provided the original author(s) and the copyright owner(s) are credited and that the original publication in this journal is cited, in accordance with accepted academic practice. No use, distribution or reproduction is permitted which does not comply with these terms. 